\title{
Correction to: Dry Metal Shaping and Forming
}

\author{
HEINZ PALKOWSKI (iD) ${ }^{1,3}$ and FRANK VOLLERTSEN ${ }^{2}$ \\ 1.-IMET - Institute of Metallurgy, TU Clausthal, 38678 Clausthal-Zellerfeld, Germany. 2.-bias - \\ Bremen Institute for Applied Beam Technology, 28359 Bremen, Germany. \\ 3.—e-mail: heinz.palkowski@tu-clausthal.de
}

\section{CORRECTION TO:}

JOM, VOL. 72, NO. 7, 2020

HTTPS://DOI.ORG/10.1007/S11837-020-04189-2

The article Dry Metal Shaping and Forming written by Palkowski and Vollertsen was originally published electronically on the publisher's internet portal on May 14, 2020 without open access. With the author(s)' decision to opt for Open Choice the copyright of the article changed on June 24, 2021 to (C) The Author(s) 2020 and the article is forthwith distributed under a Creative Commons Attribution 4.0 International License, which permits use, sharing, adaptation, distribution and reproduction in any medium or format, as long as you give appropriate credit to the original author(s) and the source, provide a link to the Creative Commons license, and indicate if changes were made.

The images or other third party material in this article are included in the article's Creative Commons licence, unless indicated otherwise in a credit line to the material. If material is not included in the article's Creative Commons licence and your intended use is not permitted by statutory regulation or exceeds the permitted use, you will need to obtain permission directly from the copyright holder.

Publisher's Note Springer Nature remains neutral with regard to jurisdictional claims in published maps and institutional affiliations. 